\title{
ANALISIS DAYA SAING DAN FAKTOR-FAKTOR YANG MEMENGARUHI EKSPOR BAN INDONESIA KE KAWASAN AMERIKA LATIN
}

\author{
Mia Ayu Wardani ${ }^{1}$, Sri Mulatsih ${ }^{2}$ \\ ${ }^{1}$ Mahasiswa Ilmu Ekonomi FEM IPB \\ ${ }^{2}$ Staf Pengajar FEM IPB
}

\begin{abstract}
The tire industry is an industry that has potential to increase Indonesian exports to non-traditional markets such as Latin America. The purpose of the study is to analyze the power of the comparative, competitive, and export dynamic of Indonesian tire and also the factors that affect the export of Indonesian tire to Latin America. The period of analysis used in this study is from 2009 to 2014 using the method of analysis are Revealed Comparative Advantage (RCA), Export Product Dynamic (EPD), Gravity models and Porter's Diamond. The results of this study are rubber tire Indonesia has strong competitiveness in Latin America than in the country of Argentina. In addition, the rubber tire Indonesia has a good export dynamics position (rising star) in the country of Panama, Venezuela, Uruguay, Mexico, Guatemala, and Costa Rica. Factors that affect the export of Indonesian rubber tire to Latin America is the distance economies, Indonesia's per capita real GDP, real GDP per capita of the destination country, the real exchange rate, and the population of the destination country.
\end{abstract}

Keywords: Competitiveness, Gravity Model, Porter's Diamond,Tire

\section{PENDAHULUAN}

Indonesia sebagai negara berkembang selalu terkena dampak dari perubahan perekonomian dunia. Krisis ekonomi global yang terjadi pada tahun 2008, berdampak pada pada kinerja ekspor Indonesia. Selama ini tujuan pasar ekspor Indonesia tergantung pada lima negara utama yaitu Amerika, Jepang, Singapura, Tiongkok, dan Malaysia. Nilai ekspor Indonesia ke negara tujuan utama sebelum dan setelah adanya krisis ekonomi global disajikan pada Gambar 1.

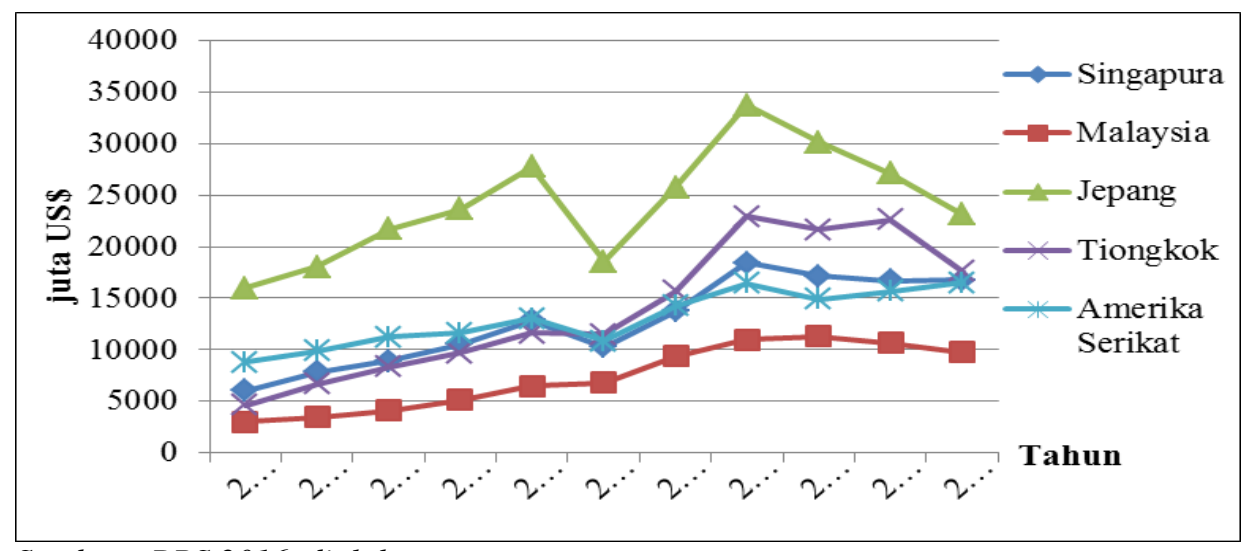

Sumber : BPS 2016, diolah

Gambar 1 Ekspor Indonesia ke negara tujuan utama 
Setelah krisis tahun 2008 nilai ekspor Indonesia ke 5 negara tujuan utama cenderung berfluktuasi. Bahkan di Jepang, Malaysia, dan Singapura tren cenderung menurun pada empat tahun terakhir. Krisis menyebabkan penurunan daya beli di negara-negara tujuan ekspor, sehingga impor barang dari Indonesia berkurang.

Fenomena tersebut mengidikasikan perlunya melakukan diversifikasi pasar tujuan ekspor untuk mengurangi ketergantungan pada negara tertentu. Ketergantungan tinggi pada negara tertentu sebagai tujuan ekspor, sangat beresiko ketika negara tujuan tersebut mengalami goncangan ekonomi.
Negara-negara berkembang di kawasan Amerika Latin memiliki potensi pasar yang besar. Namun ekspor Indonesia ke kawasan tersebut masih relatif kecil (Gambar 2). Ekspor Indonesia ke Amerika latin pasca krisis tahun 2008, menunjukkan tren yang positif, meskipun pada ketika ekspor Indonesia ke dunia secara umum mengalami (BPS, 2016). Data Kementrian Perdagangan, menunjukkan ekspor nonmigas Indonesia tahun 2010 sekitar US\$ 6.87 miliar, tahun 2014 menjadi US\$ 5.72 miliar (turun $5.73 \%$ ). Oleh karena itu perlu dilakukan strategi untuk meningkatkan ekspor ke negaranegara di kawasan Amerika Latin.

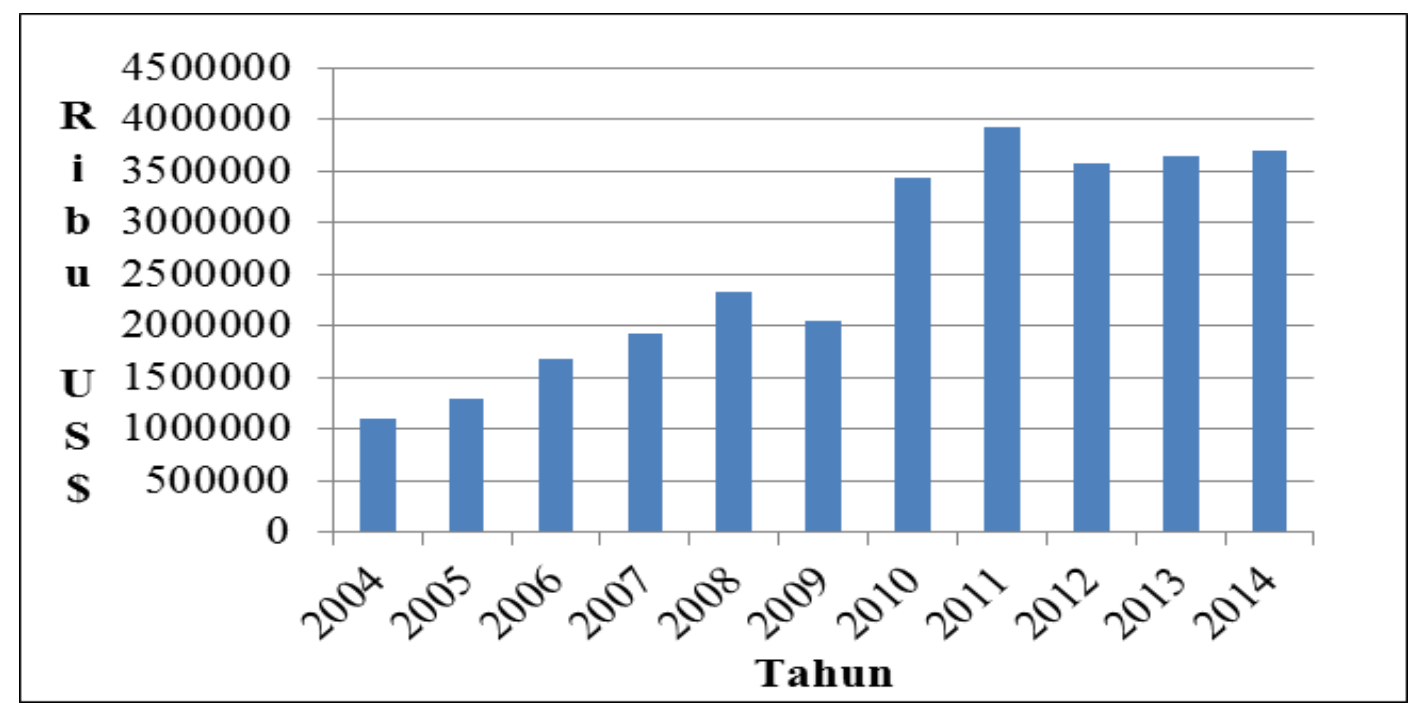

Sumber : Trade Map, 2016, diolah.

Gambar 2 Perkembangan ekspor Indonesia ke Amerika Latin

Penerimaan ekspor akan semakin tinggi, apabila bisa mengekspor produkproduk olahan. Salah satu produk olahan berbahan baku lokal adalah karet alam. Negara Indonesia merupakan salah satu negara produsen karet alam terbesar di dunia. Produksi dan luas lahan karet alam Indonesia mengalami peningkatan yang signifikan hingga tahun 2015, bahkan produktivitasnya juga terus meningkat (Ditjenbun, 2016).

Menurut

Kementrian

Perindustrian (2016), pengguna karet alam utama di Indonesia adalah industri ban (sebesar 55\%) serta industri sarung tangan dan benang karet (17\%). Lainnya digunakan oleh industri alas kaki (11\%), dan 9\% oleh industri barang-barang karet lain. Upaya untuk meningkatkan ekspor ban, dapat membantu meningkatkan kesejahteraan petani karet, karena meningkatkan daya serap pasar karet alam.

Kawasan Amerika Latin merupapasar ban potensial. Ekspor ban Indonesia ke Amerika Latin setelah 
krisis (2009-2014) meningkat tajam (Gambar 3). Nilai ekspor tahun 2009 sebesar US\$ 14,245,000. Tahun 2010 meningkat menjadi US\$ 31,380,000, dan tahun 2014 mencapai US\$ $69,200,000$.

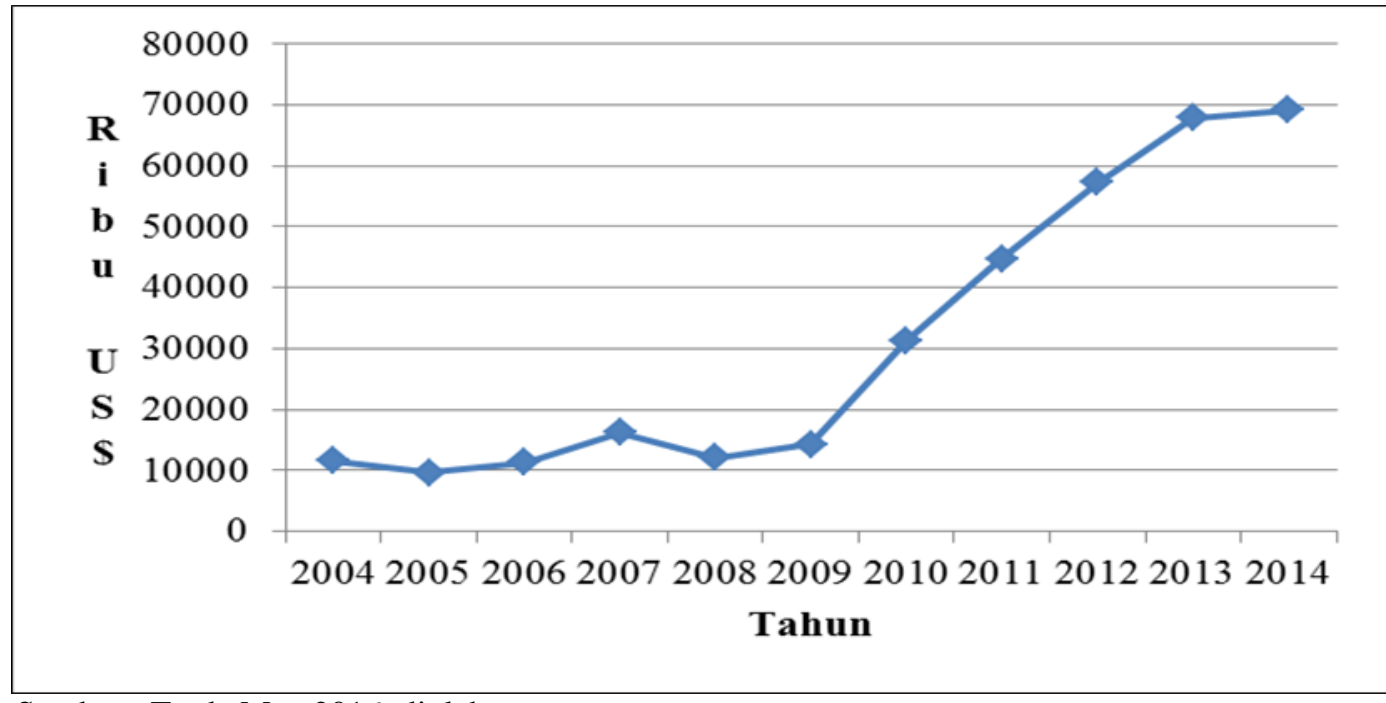

Sumber : Trade Map 2016, diolah.

Gambar 3 Ekspor ban Indonesia di Amerika Latin Ekspor ban Indonesia di Amerika Latin

Negara-negara dengan permintaan impor ban tinggi adalah Brazil dan Meksiko (UNComtrade, 2016), seperti ditujukkan pada Gambar 4. Negara lainnya seperti Kolombia,
Paraguay, Argentina, Panama, Guatemala, Venezuela, Uruguay, dan Costa Rica relatif kecil, namun permintaannya selalu meningkat.

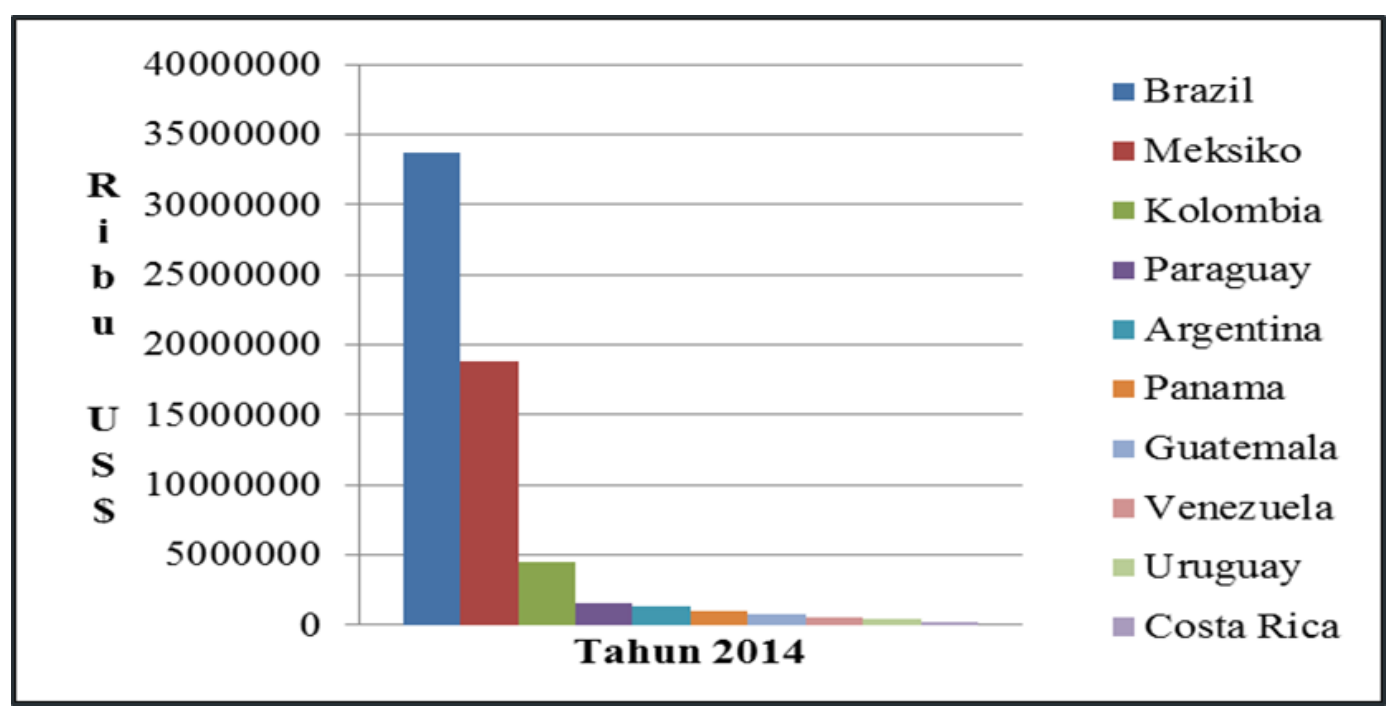

Sumber : UNCOMTRADE 2016, diolah.

Gambar 4 Ekspor ban Indonesia ke sepuluh Negara utama di Amerika Latin

Terkonsentrasinya ekspor ban di dua negara, menjadi tantangan sekaligus ancaman bagi Indonesia karena banyak negara lain (seperti Tiongkok, Jepang, Korea, Thailand dan India) yang juga mengekspor ban ke Brazil dan 
Meksiko,. Posisi pasar ban Indonesia di Amerika Latin perlu selalu dipantau (market intelegent) untuk mempertahankan atau bahkan meningkatkan dayasaing ban terhadap produk yang sama dari negara lain. Demikian juga, pasar ban perlu diperluas, agar bisa dicapai economic of scale dari segi biaya transport, yang selajutnya dapat meningkatkan dayasaing. Penelitian ini bertujuan untuk: 1) mengetahui perkembangan daya saing komparatif dan dinamika ekspor ban Indonesia ke kawasan Amerika Latin, 2) mengetahui faktor ekonomi apa saja yang memengaruhi ekspor ban Indonesia ke kawasan Amerika Latin, serta 3) mengetahui daya saing kompetitif sebagai dasar untuk menetapkan strategi kebijakan untuk melakukan diversifikasi pasar ekspor ban Indonesia

\section{TINJAUAN PUSTAKA}

\section{Perdagangan dan Dayasaing}

Secara teoritis, perdagangan internasional terjadi karena dua alasan utama. Pertama, negara-negara berdagang karena kemampuan setiap negara berbeda satu sama lain sehingga setiap negara dapat memperoleh keuntungan dengan melakukan perdagangan. Kedua, negara-negara melakukan perdagangan untuk mencapai skala ekonomi (economic of scale) dalam produksi (Basri dan Munandar, 2010).

Daya saing merupakan kemampuan suatu komoditi untuk memasuki pasar luar negeri dan kemampuan untuk dapat bertahan di dalam pasar tersebut. Jika suatu produk mempunyai daya saing maka produk tersebut akan diminati oleh konsumen. Menurut Porter (1990), keunggulan daya yang menentukan saing suatu komoditi dikelompokkan menjadi dua macam, yaitu keunggulan alamiah/keunggulan absolut (natural advantage) dan keunggulan yang dikembangkan (acquired advantage). Pendekatan yang sering digunakan untuk mengukur daya saing komoditi adalah faktor keunggulan komparatif (comparative advantage) dan faktor keunggulan kompetitif (competitive advantage).

\section{Teori Keunggulan Komparatif dan Kompetitive}

Teori Keunggulan Komparatif yang dibangun David Ricardo menggunakan asumsi sebagai berikut: (1) berlakunya labor theory of value, yaitu bahwa nilai suatu barang ditentukan oleh jumlah tenaga kerja yang digunakan; (2) tidak memperhitungkan biaya transportasi; (3) produksi dijalankan dengan biaya tetap, sedangkan skala produksi bersifat constant return to scale; serta (4) faktor produksi tidak bersifat mobile antarnegara (Salvatore, 1997). Hecker dan Ohlin dalam Salvatore (1997) menjelaskan mengenai terbentuknya keunggulan komparatif David Ricardo, yang dikenal sebagai teorema $\mathrm{H}-\mathrm{O}$. Teori $\mathrm{H}-\mathrm{O}$ merupakan model tentang analisis perdagangan antar dua negara, yang mempunyai karakteristik berbeda.

Teori Keunggulan Kompetitif adalah sebuah konsep yang menyatakan bahwa kondisi alami tidak perlu dijadikan penghambat karena pada dasarnya dapat diperjuangkan dengan berbagai usaha. Keunggulan suatu negara bergantung pada kemampuan perusahaan di dalam negara tersebut untuk berkompetisi menghasilkan produk yang dapat bersaing di pasar (Porter, 1990). Terdapat empat faktor utama yang membentuk lingkungan dimana perusahaan bisa kompetitif, yaitu: 1) Kondisi faktor produksi (factor conditions), perusahaan lokal 
berkompetisi sedemikian rupa, sehingga mendorong terciptanya keunggulan misalnya tenaga kerja terampil, infrastruktur, dan teknologi; (2) Kondisi permintaan (demand conditions); (3) Industri terkait dan industri pendukung (related and supporting industries); (4) Strategi, struktur dan persaingan perusahaan, yakni kondisi dalam negeri yang menentukan bagaimana perusahaan-perusahaan dibentuk, diorganisasikan, dan dikelola serta sifat persaingan domestik

\section{Konsep Gravity Model}

Gravity model pertama kali diterapkan oleh Tinbergen (1962) untuk meneliti aliran perdagangan internasional. Spesifikasi model adalah total ekspor sebagai fungsi PDB dan jarak diantara negara yang melakukan perdagangan (Deardoff, 1997). Model ini meniru hukum gravitasi Newton, bahwa gaya gravitasi antara dua benda dipengaruhi secara proporsional oleh massa dari kedua benda (dicerminkan oleh pendapatan nasional masingmasing negara) dan jarak kuadrat antara keduanya (dicerminkan oleh jarak ekonomi). Model ini menyatakan bahwa intensitas perdagangan antar negara berhubungan positif pendapatan nasional dan berhubungan negatif dengan jarak antara dua negara (Yuniarti, 2007).

\section{Jarak Ekonomi}

Jarak merupakan proksi untuk biaya transportasi. Krugman (2011) menyatakan bahwa jarak antara dua negara menjadi determinan penting dalam pola perdagangan secara geografis, karena jarak dapat meningkatkan biaya transportasi, meskipun jarak bukan satu-satunya biaya yang harus ditanggung.
$\mathrm{Li}$, et al (2008) mengganti variabel jarak dengan jarak ekonomi rata-rata yang telah dibobotkan untuk menunjukkan biaya perdagangan. Jarak ekonomi dihitung sesuai rumus:

dimana,

$$
D I S T_{\text {country.f }}=\frac{D I S T_{f} * G D P_{f}}{\sum_{f}^{n} G D P_{f}}
$$

dimana,

$$
D I S T_{\text {country.f }}=\frac{D I S T_{f} * G D P_{f}}{\sum_{f}^{n} G D P_{f}}
$$

DIST $_{\text {country.f }} \quad=$ jarak ekonomi antar negara pada tahun $\mathrm{f}$

$D_{\text {IST }} \quad=$ jarak geografis antar negara pada tahun $\mathrm{f}$

$G D P_{f} \quad=$ GDP negara pada tahun $\mathrm{f}$

Penggunaan jarak ekonomi rata-rata yang telah dibobotkan diharapkan dapat mengukur dampak biaya transportasi dan biaya lainnya terhadap arus perdagangan bilateral.

\section{Gross Domestic Product (GDP)}

GDP riil digunakan dalam pemodelan gravity model karena ukuran kemakmuran ekonomi dari suatu negara lebih baik dihitung menggunakan nilai output barang dan jasa yang tidak dipengaruhi oleh perubahan harga (Mankiw, 2007). Selain GDP nominal dan GDP riil, terdapat pula GDP perkapita. GDP perkapita merupakan pendapatan rata-rata penduduk disuatu negara pada waktu tertentu yang dapat digunakan sebagai salah satu indikator untuk mengukur tingkat konsumsi atau kemampuan daya beli suatu negara atas barang dan jasa. GDP perkapita yang tinggi mengindikasikan bahwa negara tersebut dapat dijadikan peluang jangkauan pasar bagi kegiatan ekspor (Karlinda, 2012). 


\section{Nilai Tukar}

Nilai tukar yang digunakan pada permodelan gravity model adalah nilai tukar riil dari negara tujuan terhadap Dollar, karena sebagian besar negara menggunakan mata uang dollar untuk berdagang. Terdapat hubungan yang positif antara nilai tukar riil negara tujuan dengan nilai ekspor dari negara lain (Mankiw, 2007). Perhitungan nilai tukar riil menggunakan rumus berikut:.

$$
\begin{aligned}
& \text { Nilai Tukar Riil } \\
& \quad=\text { Nilai tukar nominal } \\
& \times \frac{\text { IHK Domestik }}{\text { IHK Negara Tujuan }}
\end{aligned}
$$

\section{Populasi}

Populasi penduduk dapat menunjukkan ukuran suatu negara. Head dan Mayer (2013) menyatakan bahwa ekspor meningkat secara proporsional sesuai dengan ukuran ekonomi negara tujuan ekspor. Menurut Salvatore (1997), populasi suatu negara yang terus bertambah berpengaruh pada ekspor suatu komoditi melalui sisi penawaran dan permintaan. Pada sisi permintaan, berdampak pada bertambah besarnya permintaan domestik. Pada sisi penawaran adalah bertambahnya tenaga kerja untuk melakukan produksi komoditi ekspor.

\section{Penelitian Terdahulu}

Pradipta dan Firdaus (2014) dan Haditaqy (2015) meneliti tentang posisi daya saing dan faktor-faktor yang memengaruhi ekspor, menggunakan metode RCA, EPD dan Gravity Model. Nayantakaningtyas dan Daryanto (2012) menganalisis daya saing produk Crude Palm Oil (CPO) Indonesia di pasar internasional megunakan metode RCA dan Porter's Diamond.

Karagoz dan Saray (2009) menganalisis tentang Potensi perdagangan Turki dengan negaranegara Asia Pasifik menggunakan pendekatan Gravity Model. Metode untuk pemilihan model yang digunakan adalah fixed effect model. Variabel dependen dalam penelitian ini adalah volume perdagangan antara Turki dengan negara-negara Asia Pasifik, sedangkan variabel independen adalah GDP negara tujuan, jarak antar kedua negara yang melakukan perdagangan, dan populasi negara tujuan ekspor. Data yang digunakan adalah 23 negara anggota APEC (kecuali negara Laos, Cambodia, dan Myanmar). Hasil dari penelitian ini adalah GDP berpengaruh positif dan jarak berpengaruh negatif terhadap volume perdagangan antara turki dan negara-negara Asia Pasifik. Sedangkan populasi tidak berpengaruh secara signifikan. Negara-negara yang berpotensi untuk menjadi mitra dagang Turki adalah P.N Guinea, Myanmar, Mexico, Laos, dan Brunei Darussalam.

Acharya (2013) meneliti tentang analisis data panel pada faktor yang memengaruhi perdagangan Nepal dengan pendekatan gravity model. Data yang digunakan adalah data panel dengan 21 negara mitra dagang dan 6 tahun penelitian. Metode yang digunakan adalah metode gravity model dengan variabel dependennya adalah ekspor, impor, dan neraca perdagangan, sedangkan variabel independennya adalah GDP riil Nepal dan negara mitra dagang, populasi Nepal dan mitra dagang, jarak, dummy SAFTA, OECD, dan freedom of country. Hasil penelitian ini adalah ekspor dan impor Nepal sangat dipengaruhi oleh GDP riil negara mitra dagang. GDP riil Nepal berpengaruh positif namun tidak signifikan terhadap ekspor Nepal, jarak antara Nepal dengan negara mitra dagang berpengaruh negatif dan siginifikan, populasi Nepal dan negara mitra dagang berpengaruh negatif terhadap ekspor Nepal. Nepal lebih banyak ekspor pada SAFTA dibanding 
negara non SAFTA dan lebih sedikit mengimpor dari OECD dibanding negara non-OECD.

Pendekatan gravity model juga digunakan oleh Hatab, et al.(2010) menganalisis tentang faktor yang memengaruhi ekspor produk pertanian Mesir ke negara tujuan utama dengan pendekatan gravity model. Data yang digunakan dalam penelitian ini adalah data panel dengan data cross section berupa 96 negara pengimpor produk pertanian dan data time series berupa periode penelitian selama 15 tahun dari 1994 hingga 2008. Hasil penelitian ini adalah GDP negara tujuan ekspor berpengaruh positif terhadap perdagangan mesir sedangkan jarak berpengaruh negatif terhadap perdagangan mesir. Namun, GDP perkapita negara pengimpor tidak berpengaruh secara signifikan terhadap ekspor produk pertanian Mesir. Hal ini dikaitkan dengan fakta pertumbuhan ekonomi, disamping peningkatan populasi dan peningkatan permintaan perkapita untuk semua barang normal. Volatilitas nilai tukar memiliki koefisien positif yang signifikan, menunjukkan bahwa depresiasi Pound Mesir terhadap mata uang mitra dagangnya memengaruhi peningkatan ekspor pertanian Mesir. Biaya transportasi yang tercermin pada jarak memiliki pengaruh yang negatif pada ekspor pertanian Mesir. Hasil dari penelitian ini juga menjelaskan bahwa ekspor mesir meningkat pada negara-negara yang menggunakan bahasa Arabic, namun adanya kerjasama regional justru tidak berpengaruh signifikan pada ekspor Mesir.

Yuniarti (2007) menganalisis
tentang determinan perdagangan
bilateral Indonesia dengan pendekatan
gravity model. Metode yang digunakan
adalah metode panel data dengan 10
negara mitra dagang Indonesia dan

periode waktu selama 31 tahu dari 1970 hingga 2000. Hasil penelitian ini adalah pendapatan domestik, populasi, dan ukuran ekonomi memiliki dampak positif pada perdagangan bilateral Indonesia, sementara jarak memiliki dampak negatif pada perdagangan bilateral Indonesia. Faktor endowment dan kerjasama perdagangan regional tidak berdampak pada perdagangan indonesia.

\section{METODE PENELITIAN}

\section{Jenis dan Sumber Data}

Penelitian ini menggunakan data sekunder. Data tahunan panel dengan time series tahun 2009 sampai 2014, dan cross section sepuluh negara di kawasan Amerika Latin, (Brazil, Meksiko, Kolombia, Paraguay, Argentina, Panama, Guatemala, Venezuela, Uruguay, dan Costa Rica) diambil dari Trade Map (data nilai ekspor ban), UNCTAD (data GDP, indek harga konsumen), dan World bank (data nilai tukar), dan CEPII (data jarak geografis).

\section{Metode Analisis Data}

Metode analisis yang digunakan adalah, Revealed Comparative Advantage (RCA), Export Product Dynamic (EPD), Porter's Diamond dan Gravity Model.

Metode RCA, untuk mengukur keunggulan komparatif ban Indonesia dibandingkan dengan negara lain, menggunakan rumus berikut ini (Balassa, 1965):

$$
R C A=\frac{X_{i j} / X_{j}}{X_{i w} / X_{w}}
$$

Keterangan:

$$
\begin{aligned}
& X_{i j}= \begin{array}{l}
\text { Nilai ekspor ban Indonesia ke } \\
\text { negara tujuan ekspor }
\end{array} \\
& X_{j}=\begin{array}{l}
\text { Nilai total ekspor Indonesia ke } \\
\text { negara tujuan ekspor }
\end{array}
\end{aligned}
$$




$$
\begin{aligned}
X_{i w}= & \text { Nilai ekspor ban dunia ke } \\
& \text { negara tujuan ekspor } \\
X_{w}= & \text { Nilai total ekspor dunia ke } \\
& \text { negara tujuan ekspor } \\
i \quad= & \text { Ban Indonesia } \\
j & =\text { Indonesia } \\
w \quad= & \text { Dunia }
\end{aligned}
$$

Jika nilai $\mathrm{RCA}>1$, berarti produk tersebut memiliki keunggulan komparatif atau berdaya saing kuat. Sebaliknya jika nilai RCA $<1$, maka produk tersebut tidak memiliki keunggulan komparatif atau berdaya saing lemah.

Export Product Dynamic (EPD) digunakan untuk mengukur dinamika posisi pasar ban Indonesia di negara tujuan ekspor. Matrik EPD menggunakan daya tarik pasar (diukur berdasarkan pertumbuhan permintaan) sebagai sumbu horisontal (sumbu X) dan kekuatan bisnis (diukur dari pertumbuhan perolehan pasar/market share) sebagai sumbu vertikal (sumbu Y), menghasilkan 4 kategori posisi pasar (Gambar 5) yaitu rising star, falling star, lost opportunity, dan retreat (Esterhuizen, 2006). Posisi pasar yang ideal adalah rising star yang mendindikasikan suatu negara meraih pangsa pasar tinggi pada produk yang dinamis (permintaannya tumbuh cepat). Posisi lost opportunity merupakan posisi pasar yang paling tidak diinginkan karena mengindikasi suatu negara kehilangan pangsa pasar pada produk yang dinamis. Posisi falling star juga tidak diinginkan, meskipun lebih baik jika dibandingkan dengan lost opportunity karena pangsa pasar suatu negara meningkat pada produk yang tidak dinamis. Posisi retreat mungkin tidak diinginkan, tetapi dapat menjadi masukan untuk beralih pada produk lainnya yang dinamis (Esterhuizen, 2006).

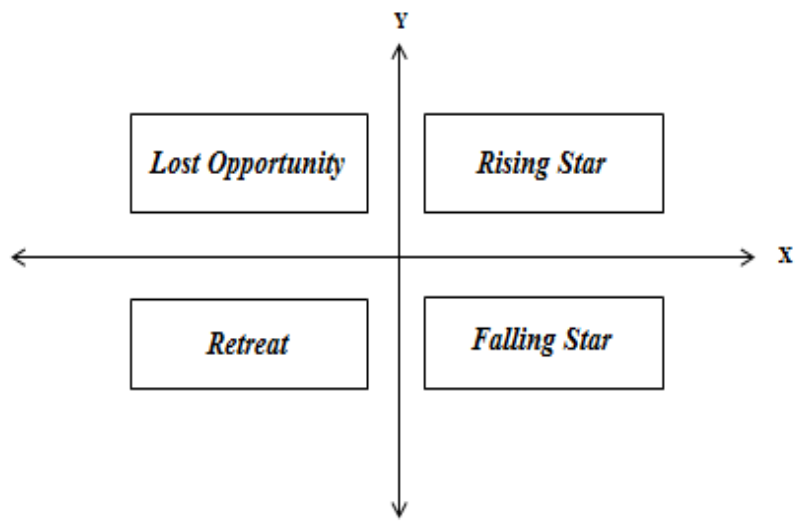

Gambar 5 Matriks EPD

Sumbu x : Pertumbuhan kekuatan bisnis atau disebut pangsa pasar ekspor i :

$\frac{\sum_{t=1}^{t}\left(\frac{X_{i j}}{W_{i j}}\right)_{t} \times 100 \%-\sum_{t=1}^{t}\left(\frac{X_{i j}}{W_{i j}}\right)_{t-1} \times 100 \%}{T}$ Sumbu y : Pertumbuhan daya tarik pasar atau disebut pangsa pasar produk :

$\sum_{t=1}^{t}\left(\frac{X_{t}}{W_{t}}\right)_{t} \times 100 \%-\sum_{t=1}^{t}\left(\frac{X_{t}}{W_{t}}\right)_{t-1} \times 100 \%$

Keterangan :

$X_{i j}$ : Nilai ekspor ban Indonesia ke negara tujuan ekspor

$W_{i j}$ : Nilai ekspor ban dunia ke negara tujuan ekspor

$X_{t}$ : Nilai total ekspor Indonesia ke negara tujuan ekspor

$W_{t}$ : Nilai total ekspor dunia ke negara tujuan ekspor

$T$ : Jumlah tahun analisis

Analisis gravity model untuk menduga faktor-faktor yang berpengaruh terhadap aliran ekspor ban Indonesia ke kawasan Amerika Latin. Rumus yang digunakan adalah sebagai berikut.

$$
\begin{aligned}
\operatorname{LnEXP}_{t}= & \alpha_{0}+\beta_{1} \operatorname{LnGDPRPI}_{t}+ \\
& \beta_{2} \operatorname{LnGDPRPN}_{j t}+ \\
& \beta_{3} \operatorname{LnPOP}_{j t}+ \\
& \beta_{4} \operatorname{LnNTR}_{j t}+\beta_{5} \operatorname{LnJE}_{j t}+\varepsilon_{i t}
\end{aligned}
$$




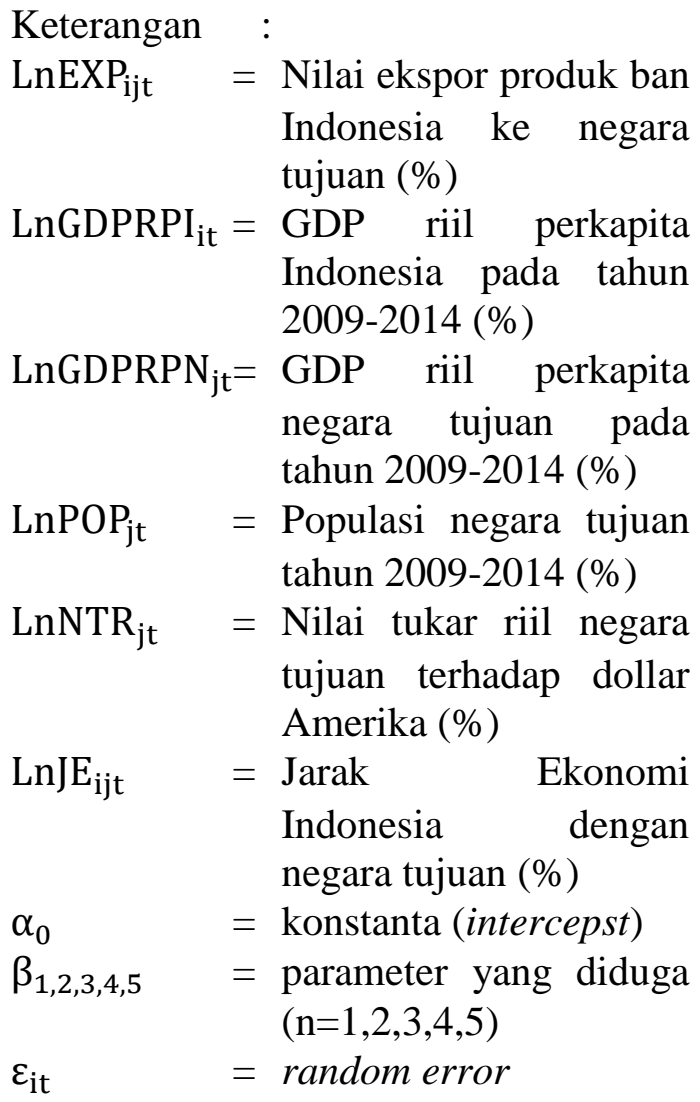

Definisi operasional dari masingmasing variabel penelitian adalah sebagai berikut:

1. Nilai ekspor merupakan nilai ekspor ban Indonesia ke 10 negara Amerika Latin yang diteliti dalam satuan US\$.

2. GDP Indonesia adalah GDP riil perkapita Indonesia dalam satuan US\$.

3. GDP negara tujuan adalah GDP riil perkapita negara tujuan ekspor ban Indonesia dalam satuan US\$.

4. Populasi adalah jumlah penduduk negara tujuan ekspor ban Indonesia.

5. Nilai tukar adalah nilai tukar riil negara tujuan ekspor ban Indonesia terhadap mata uang Amerika Serikat.

6. Jarak ekonomi dihitung dengan rumus $\mathrm{Li}$, et al (2008).
Daya saing kompetitif ekspor ban Indonesia dianalisis menggunakan metode Porter's Diamond, berdasarkan 4 komponen yaitu:

1. Factor Condition (FC), yaitu keadaan faktor-faktor produksi dalam industri ban seperti tenaga kerja dan infrastuktur.

2. Demand Condition (DC), yaitu keadaan ekspor permintaan ban.

3. Related and Supporting Industries (RSI), yaitu keadaan para penyalur dan industri lainnya yang mendukung dan berhubungan dengan ekspor ban.

4. Firm, Strategy, Structur, and Rivalry (FSSR), yaitu strategi yang dianut perusahaan pada umumnya, stuktur industri dan keadaan kompetisi ekspor ban.

Keempat faktor utama diatas didukung oleh dua faktor lain yaitu faktor pemerintah dan faktor kesempatan. Dari hasil analisis enam komponen Porter's Diamond, dapat ditentukan kelebihan (+) dan kekurangan (-) ekspor ban Indonesia.

\section{HASIL DAN PEMBAHASAN}

Industri ban di Indonesia terdiri dari 11 perusahaan yang tergabung dalam Asosiasi Perusahaan Ban Indonesia (APBI) (Tabel 1). Produksi ban dari 11 perusahaan tersebut, setiap tahun mengalami peningkatan (Tabel 2), kecuali tahun 2013 dimana produksi dan penjualan ban mobil turun masingmasing $5.7 \%$ dan $4.6 \%$ dibandingkan tahun sebelumnya. Penurunan ini disebabkan oleh menurunnya ekspor (yang merupakan bagian terbesar dari penjualan), sebesar $11.3 \%$ akibat krisis ekonomi. 
Tabel 1 Daftar perusahaan ban Indonesia

\begin{tabular}{clll}
\hline No & Nama Perusahaan & Ban Roda-4 & Ban Roda-2 \\
\hline 1 & PT. Goodyear Indonesia Tbk & Produksi & - \\
2 & PT. Bridgestone Tire Indonesia & Produksi & - \\
3 & PT. Gajah Tunggal Tbk & Produksi & Produksi \\
4 & PT. Industri Karet Deli & Produksi & Produksi \\
5 & PT. Sumi Rubber Indonesia & Produksi & Produksi \\
6 & PT. Suryaraya Rubberindo Industries & - & Produksi \\
7 & PT. Elangperdana Tyre Industry & Produksi & - \\
8 & PT. Benteng Pratama Rubber Co.Ltd & - & Produksi \\
9 & PT. Hung-A Indonesia & - & Produksi \\
10 & PT. United King-Land & - & Produksi \\
11 & PT. Surabaya Kencana Anugerah & - & Produksi \\
\hline
\end{tabular}

Sumber : Laporan tahunan APBI 2013

Produksi ban dari 11 perusahaan tersebut, setiap tahun mengalami peningkatan (Tabel 2), kecuali tahun 2013 dimana produksi dan penjualan ban mobil turun masing-masing 5.7\% dan $4.6 \%$ dibandingkan tahun sebelumnya. Penurunan ini disebabkan oleh menurunnya ekspor (yang merupakan bagian terbesar dari penjualan), sebesar $11.3 \%$ akibat krisis ekonomi.

Tabel 2 Produksi ban Indonesia

\begin{tabular}{crrrrrr}
\hline \multirow{2}{*}{ Jenis Ban } & \multicolumn{6}{c}{ Jumlah Produksi (ribu unit) } \\
\cline { 2 - 7 } & 2008 & 2009 & 2010 & 2011 & 2012 & 2013 \\
\hline Ban Mobil (roda-4) & 42,853 & 39,132 & 50,016 & 51,896 & 50,261 & 47,420 \\
Ban Motor (roda-2) & 28,804 & 28,467 & 40,482 & 41,745 & 47,120 & 54,843 \\
\hline
\end{tabular}

Sumber : Laporan tahunan APBI 2013

Tabel 3 Penjualan ban Indonesia

\begin{tabular}{|c|c|c|c|c|c|c|c|}
\hline \multirow{2}{*}{\multicolumn{2}{|c|}{ Penjualan }} & \multicolumn{6}{|c|}{ Jumlah Penjualan (ribu unit) } \\
\hline & & 2008 & 2009 & 2010 & 2011 & 2012 & 2013 \\
\hline \multirow[t]{2}{*}{ Replacement } & Ban Mobil & 8,829 & 8,450 & 10,497 & 11,089 & 11,933 & 13,050 \\
\hline & Ban Motor & 15,963 & 15,358 & 23,510 & 23,919 & 30,980 & 36,272 \\
\hline \multirow[t]{2}{*}{ OEM } & Ban Mobil & 3,408 & 2,579 & 3,982 & 4,336 & 5,517 & 5,746 \\
\hline & Ban Motor & 12,538 & 11,835 & 15,163 & 16,065 & 14,558 & 15,999 \\
\hline \multirow[t]{2}{*}{ Ekspor } & Ban Mobil & 30,128 & 28,000 & 34,701 & 35,979 & 32,083 & 28,469 \\
\hline & Ban Motor & 780 & 1,096 & 1,254 & 1,334 & 1,501 & 1,893 \\
\hline \multirow{2}{*}{ Total } & Ban Mobil & 42,365 & 39,029 & 49,180 & 51,404 & 49,533 & 47,265 \\
\hline & Ban Motor & 29,281 & 28,289 & 39,927 & 41,318 & 47,039 & 54,164 \\
\hline
\end{tabular}

Sumber : Laporan tahunan APBI 2013

Karet alam dan karet sintetis merupakan bahan baku utama produksi ban. Pemakaian karet alam dan sintetis tahun 2013 mengalami penurunan antara $7 \%$ dan $8 \%$ dibandingkan pada tahun 2012. Faktor produksi lainnya 
yaitu tenaga kerja, penyerapannya terus ditunjukkan pada Tabel 4. meningkat setiap tahunnya seperti

Tabel 4 Penggunaan input industri ban Indonesia

\begin{tabular}{lrrrrrr}
\hline Input & \multicolumn{7}{c}{ Tahun } \\
\cline { 2 - 7 } & 2008 & 2009 & 2010 & 2011 & 2012 & 2013 \\
\hline $\begin{array}{l}\text { Penyerapan tenaga kerja } \\
\text { (orang) }\end{array}$ & 23,436 & 23,808 & 27,01 & 28,116 & 30,332 & 31,076 \\
Karet alam (ton) & 164,629 & 150,564 & 189,78 & 196,109 & 206,54 & 190,336 \\
Karet sintetis (ton) & 125,034 & 116,936 & 149,978 & 166,35 & 164,429 & 150,606 \\
Total Karet (ton) & 289,663 & 267,5 & 339,758 & 362,459 & 370,969 & 340,942 \\
\hline
\end{tabular}

Sumber : Laporan tahunan APBI 2013

Secara umum,
menyimpulkan bahwa meskipun
indikator-indikator ekonomi me-
nunjukkan pelemahan, namun perekonomian dalam negeri khususnya sektor riil menunjukkan peningkatan yang cukup mendukung industri dan perdagangan baik jasa maupun manufaktur. Pertumbuhan industri ban Indonesia dipicu oleh semakin tingginya produksi dan penjualan otomotif dalam negeri, sehingga penjualan ban di pasar replacement dan pasar perakitan ikut meningkat. Disisi lain, penjualan ekspor akan membaik seiring pulihnya perekonomian dunia.

\section{Dayasaing Komparatif Ekspor Ban}

Daya saing ekspor ban Indonesia diukur menggunakan metode Revealed Comparative Advantage (RCA) dan Export Product Dynamic (EPD). Dari sepuluh negara yang diteliti, seluruhnya memiliki nilai RCA yang meningkat setiap tahunnya. Tahun 2014, hanya ada negara yang nilainya $\mathrm{RCA}<1$ yaitu pasar Argentina (Tabel 4). Artinya secara umum ban Indonesia memiliki daya saing yang tinggi di kawasan Amerika Latin.

Tabel 5 Hasil RCA produk ban Indonesia ke Amerika Latin

\begin{tabular}{lrrrrrrr}
\hline \multirow{2}{*}{ Negara } & \multicolumn{7}{c}{ Nilai RCA } \\
\cline { 2 - 7 } & 2009 & 2010 & 2011 & 2012 & 2013 & 2014 & Rata-rata \\
\hline Brazil & 1,128 & 0,783 & 0,842 & 1,963 & 3,718 & 3,804 & 2,04 \\
Meksiko & 12,748 & 10,338 & 15,297 & 27,207 & 24,684 & 47,621 & 22,98 \\
Kolombia & 0,539 & 0,754 & 0,774 & 0,885 & 1,615 & 2,598 & 1,19 \\
Paraguay & 1,697 & 4,987 & 4,997 & 6,855 & 3,987 & 4,805 & 4,56 \\
Argentina & 0,550 & 0,021 & 0,325 & 0,249 & 0,239 & 0,772 & 0,36 \\
Panama & 2,363 & 2,097 & 2,077 & 2,873 & 0,451 & 1,446 & 1,89 \\
Guatemala & 1,534 & 5,305 & 6,583 & 2,014 & 3,336 & 3,332 & 3,65 \\
Venezuela & 2,227 & 4,834 & 9,173 & 12,756 & 8,785 & 31,083 & 11,48 \\
Uruguay & 4,043 & 47,315 & 56,432 & 56,116 & 37,628 & 16,392 & 36,32 \\
Costa Rica & 14,601 & 66,556 & 55,642 & 58,384 & 48,379 & 14,844 & 43,07 \\
Rata-rata keseluruhan & & & & & & 12,76 \\
\hline
\end{tabular}

Di Kolombia nilai RCA lebih dari satu dan terus meningkat. Berarti ban
Indonesia memiliki keunggulan komparatif dan berdaya saing tinggi di 
Kolombia. Begitu pula yang terjadi di negara Venezuela, meskipun sempat terjadi penurunan pada tahun 2013 sebesar $31,1 \%$ dari 12,756 menjadi 8,785 , namun secara keseluruhan nilai RCA Venezuela memiliki tren yang positif, bahkan pada tahun 2014, RCA Venezuela meningkat secara tajam sebesar $253,8 \%$ dari 8,785 menjadi 31,083 . Hal tersebut juga terjadi pada negara meksiko, dimana terjadi peningkatan sebesar $92,9 \%$ dari 24,684 pada tahun 2013 menjadi 47.621 pada tahun 2014.

Rata-rata RCA tertinggi terjadi di Costa Rica sebesar (yaitu 43,07), selanjutnya diikuti oleh Uruguay,
Meksiko, Venezuela, Paraguay, Guatemala, Brazil, Panama, dan Kolombia. Negara Argentina memiliki nilai rata-rata RCA sebesar 0,36 yang berarti produk ban Indonesia tidak memiliki keunggulan komparatif dan berdaya saing rendah dibandingkan dengan pesaing negara produsen ban lainnya.

\section{Dinamika Ekspor}

Dinamika ekspor produk ban Indonesia di pasar Amerika Latin dianalisis dengan metode Export Product Dynamic (EPD), hasilnya disajikan pada Gambar 6.

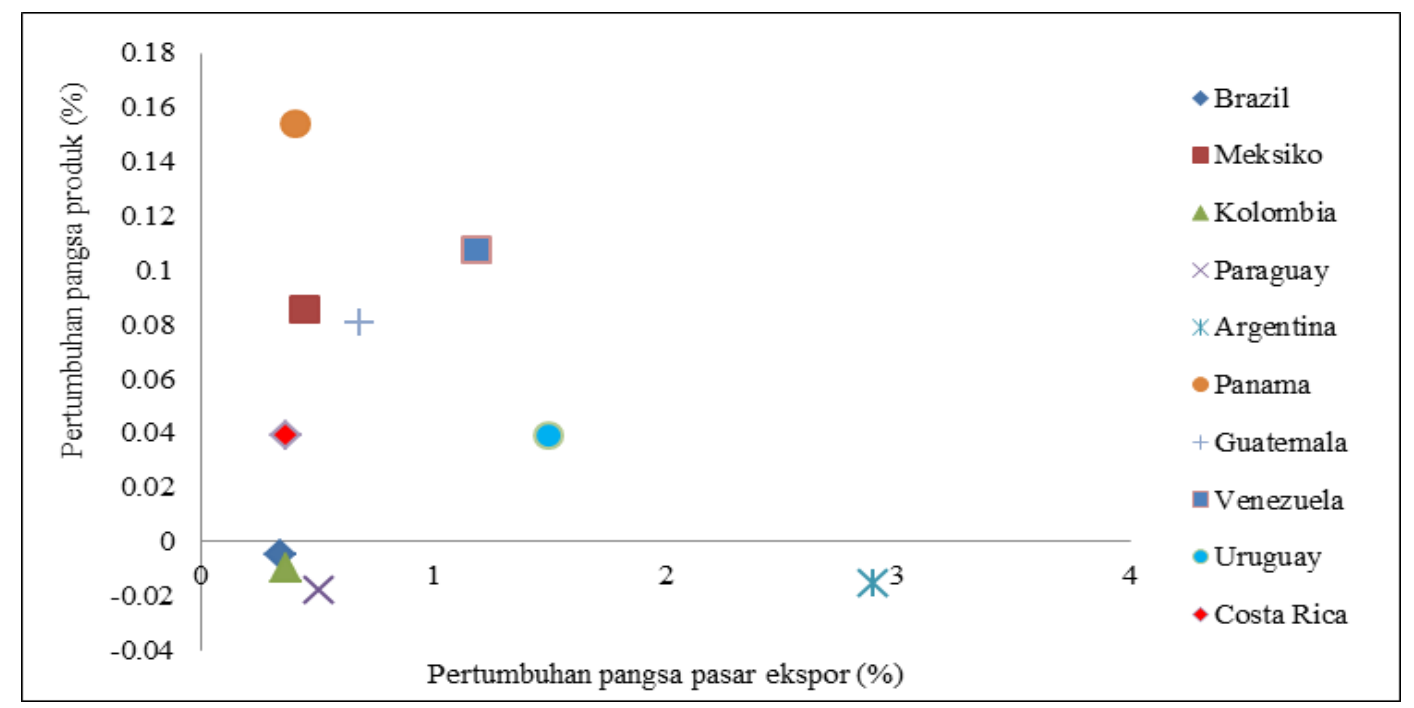

Sumber : Trade Map 2016, diolah

Gambar 6 Dinamika pasar ban Indonesia ke Amerika Latin

Gambar 6 menunjukkan bahwa pasar ban Indonesia ke Amerika Latin berada pada posisi Rising Star dan Falling Star. Terdapat enam negara yang menempati posisi Rising Star, yaitu Panama, Venezuela, Meksiko, Guatemala, Costa Rica, Uruguay. Hasil analisis EPD menunjukkan bahwa permintaan ban Indonesia meningkat setiap tahunnya, dan menjadi produk yang dinamis di Amerika Latin. Pangsa pasarnyapun memiliki pertumbuhan yang positif, sehingga dikategorikan sebagai produk yang kompetitif di pasar Amerika Latin. Pasar dengan posisi Rising Star merupakan posisi yang ideal sehingga keenam negara tersebut berpotensi untuk dijadikan tujuan ekspor produk ban Indonesia.

Sementara posisi Falling Star terjadi di pasar Brazil, Kolombia, Paraguay, dan Argentina. Di empat negara tersebut, ekspor ban Indonesia mengalami pertumbuhan pangsa ekspor yang positif, namun terdapat penurunan 
pada permintaan ekspor produk ban Indonesia.

\section{Faktor-Faktor yang Memengaruhi Ekspor Produk Ban Indonesia ke Amerika Latin}

Faktor-faktor yang memengaruhi nilai ekspor produk ban Indonesia ke kawasan Amerika Latin $\left(\mathrm{EXP}_{\mathrm{ijt}}\right)$, dianalisis menggunakan Gravity Model dengan variabel penduga yaitu: GDP riil perkapita Indonesia (GDPRPI ${ }_{i t}$ ), GDP riil perkapita negara tujuan ekspor $\left(\right.$ GDPRPN $\left._{\mathrm{jt}}\right)$, populasi negara tujuan $\left(\mathrm{POP}_{\mathrm{jt}}\right)$, nilai tukar riil negara tujuan $\left(\mathrm{NTR}_{\mathrm{jt}}\right)$, dan jarak ekonomi (JE $\left.\mathrm{jit}_{\mathrm{jt}}\right)$. Hasil uji Chow diperoleh nilai probabilitas $0.00, \quad(\alpha<5 \%)$, dan uji Hausman menghasilkan nilai probabilitas $0.0003(\alpha<5 \%)$. Kedua uji menunjukkan tolak $\mathrm{H}_{0}$, sehingga model yang terbaik adalah fixed effect dengan pembobotan cross section weighted. Nilai-nilai koefisien variabel penduga ditampilkan pada Tabel 5.

Tabel 5 Koefisien variabel penduga ekspor produk ban Indonesia ke Amerika Latin

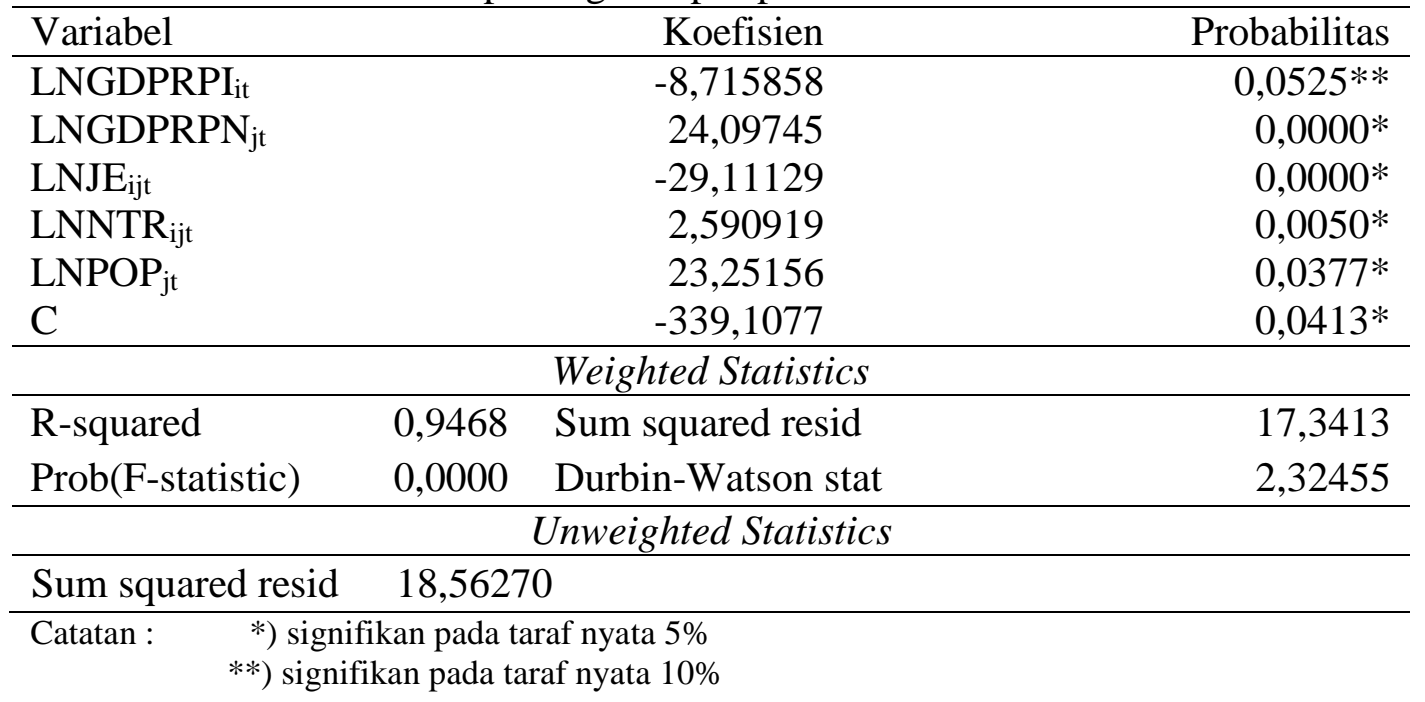

Model gravitynya adalah sebagai berikut:

$\operatorname{LnEXP}_{i j t}=-339,108-8,716 \operatorname{LnGDPRPI}_{i t}$ $+24,097 \operatorname{LnGDPRPN}_{j t}+$

23,252 LnPOP jt $+2,591$ LnNTR $_{j t}-$ $29,111 L n J E_{i j t}+\varepsilon_{i t}$

Nilai koefisien determinasi $\left(\mathrm{R}^{2}\right)$ sebesar 0,9468, berarti sekitar 94,7\% keragaman nilai ekspor produk ban Indonesia ke sepuluh negara kawasan Amerika Latin, dapat dijelaskan oleh variabel-variabel bebas yang ada, sedangkan $5,3 \%$ sisanya dijelaskan oleh faktor-faktor diluar model. Hasil uji asumsi klasik menunjukkan bahwa pada model terdapat heteroskedastisitas (nilai sum square residual pada weight statistic lebih kecil unweight statistic, yaitu $17,341<18,563$ ), namun model telah diestimasi menggunakan generalized least square, dan diberi pembobotan (cross-section weights).

Uji multikolinieritas menunjukkan adanya koefisien korelasi antar variabel penduga yang lebih besar dari 0,8 namun dapat diabaikan karena masih dibawah nilai $R$-squared (sebesar $94,7 \%$ ) dan seluruh variabel bebasnya signifikan seperti pada hasil penelitian Evasari (2014). Hasil uji normalitas menunjukkan nilai Jarque-Bera sebesar 3,954 , (lebih besar dari taraf nyata $5 \%$ 
$(3,954>0,05))$, dengan nilai probabilitas sebesar 0,139, (lebih besar dari taraf nyata $5 \%(0,139>0,05)$, sehingga, dapat disimpulkan bahwa pada model memiliki error terms yang menyebar normal. Nilai Durbin Watson (DW). sebesar 2,325 (mendekati angka dua), menunjukkan tidak terdapat masalah autokorelasi.

GDP riil perkapita Indonesia memiliki koefisien negatif $(-8,716)$ dengan probabilitas sebesar 0,0525 (signifikan pada taraf nyata $10 \%$ ). Berarti ketika GDP riil perkapita Indonesia meningkat $1 \%$, maka nilai ekspor ban Indonesia ke Amerika Latin penurunan $8,716 \%$ (ceteris paribus). Hasil ini sesuai dengan penelitian Haditaqy (2015). Peningkatan GDP riil perkapita Indonesia menunjukkan daya beli masyarakat Indonesia meningkat, sehingga konsumsi ban dalam negeri juga meningkat dan mengurangi jumlah ban yang diekspor.

GDP riil perkapita negara tujuan berpengaruh positif (24.097), menunjukkan bahwa peningkatan GDP riil perkapita negara tujuan sebesar $1 \%$ akan meningkatkan ekspor ban Indonesia sebesar 24,097\%. Peningkatan GDP negara tujuan ekspor, menunjukkan peningkatan daya beli, termasuk daya beli terhadap ban Indonesia.

Jarak ekonomi antara Indonesia dengan negara tujuan ekspor berpengaruh negatif terhadap ekspor ban Indonesia, dengan nilai koefisen penduga $-29,111$. Artinya jika jarak ekonomi bertambah 1\%, maka ekspor turun 29,111\%. Jarak ekonomi merupakan gambaran dari biaya transportasi untuk mengirim ban dari Indonesia ke kawasan Amerika Latin, sehingga meningkatnya jarak ekonomi menunjukkan biaya transportasi yang semakin tinggi dan akan mengurangi perdagangan. Hal ini sesuai dengan hukum gravitasi Newton, bahwa semakin jauh jarak antar benda, daya interaksinya makin kecil.

Nilai tukar riil antara mata uang negara tujuan dengan USD, berpengaruh positif dengan koefisien penduga 2,591. Berarti jika terjadi kenaikan nilai tukar riil terapresiasi sebesar $1 \%$ akan meningkatkan ekspor ban sebesar $2,591 \%$. Terapresiasinya nilai tukar menyebabkan harga barang-barang domestik (di negara tujuan) menjadi relatif lebih mahal dibandingkan harga barang impor, sehingga permintaan barang impor meningkat (salah satunya impor ban dari Indonesia).

Populasi negara tujuan berpengaruh positif dengan koefisien 23,251, menunjukkan jika populasi negara tujuan ekspor nasil 1\%, maka ekspor ban Indonesia akan meningkat 23,251\%. Meningkatnya jumlah penduduk di negara tujuan ekspor, akan menggeser kurva permintaan ke kanan (Lipsey et al., 1993), sehingga terjadi keseimbangan pada harga yang lebih tinggi dan jumlah diminta lebih banyak.

\section{Analisis Keunggulan Kompetitif}

Analisis keunggulan kompetitif produk ban Indonesia dapat dilihat melalui enam kondisi porter's diamond berikut.

\section{Kondisi Faktor}

1. Industri ban menyerap 55\% produksi karet alam dalam negeri (Gapkindo, 2015). (+)

2. Produktivitas karet Indonesia terus meningkat dari tahun (Ditjenbun, 2016). (+)

3. Produksi karet Indonesia pada tahun 2009 sebesar 2.440.347 ton dan terus meningkat hingga 3.231.825 ton pada tahun 2015 (Ditjenbun, 2016). (+)

4. Areal perkebunan karet meningkat dari tahun 2009 (3.435.270 ha) 
hingga tahun 2015 (3.656.057 ha) (Ditjenbun, 2016). (+)

5. Penanganan pascapanen hasil karet di tingkat petani/kelompok petani umumnya dilakukan secara sederhana (Ditjenbun, 2011). (-)

6. Penyerapan tenaga kerja industri ban meningkat, dari 23,436 (tahun 2008) hingga 31,076 (tahun 2013) dan didominasi tenaga kerja lokal. (APBI 2013). (+)

\section{Kondisi Permintaan}

1. Hasil analisis gravity model menunjukkan populasi negara tujuan berpengaruh positif terhadap ekspor ban Indonesia. (+)

2. Permintaan ban Indonesia kawasan Amerika Latin meningkat pada periode 2009-2014 (Trade Map 2016). (+)

3. Jarak antara Indonesia dengan kawasan Amerika Latin yang sangat jauh menyebabkan besarnya biaya transportasi. (-)

4. GDP perkapita kawasan Amerika Latin, tiap tahun meningkat. Berdasarkan analisis gravity model, GDP perkapita negara tujuan ekspor berpengaruh positif terhadap ekspor ban Indonesia. (UNCTAD, 2016). (+).

\section{Industri Terkait dan Pendukung}

1. Thailand, Indonesia dan Malaysia sepakat melaksanakan AETS (Agreed Export Tonnage Scheme) sejak 1 Maret 2016, untuk mengatasi rendahnya harga karet alam dan mengurangi over supply. Menurut ITRC (International Tripartite Rubber Council), ketiga negara (yang memasok $67 \%$ kebutuhan karet alam global) akan memotong jumlah ekspornya sebesar 615.000 ton dengan kuota Thailand mengurangi 324.015 ton, Indonesia 238.736 ton dan Malaysia
52.249 ton. Disamping negaranegara ITRC juga setuju untuk meningkatkan konsumsi domestiknya. (+)

2. Gapkindo (Gabungan Perusahaan Karet Indonesia) pada april 2015 mendeklarasikan meningkatkan penyerapan karet alam dalam negeri, agar tidak terjadi over suplai di pasar karet dunia (Gapkindo, 2015). (+)

3. Ban sebagai salah satu komponen kendaraan bermotor, permintaannya mengikuti pertumbuhan industri kendaraan bermotor, dimana produksi kendaraan bermotor selalu meningkat selama periode 20082013 (APBI 2013). (+)

\section{Strategi, Struktur, dan Persaingan Perusahaan}

1. Struktur pasar industri ban Indonesia bersifat oligopolistik, hanya ada beberapa perusahan dominan yaitu PT. Gajah Tunggal Tbk, PT. Bridgestone Tire Indonesia, PT. Sumi Rubber Indonesia, dan PT. Suryaraya Rubberindo Industries. (APBI, 2013)

2. Perusahaan Ban yang tergabung dalam APBI dapat melakukan kerjasama untuk meningkatkan kualitas dan kuantitas produk ban Indonesia. (+)

3. Persaingan antar produsen ban dunia makin ketat. Negara Tiongkok, Jepang, dan Amerika Serikat merupakan pesaing Indonesia dalam ekspor ban ke kawasan Amerika Latin (UNCOMTRADE, 2016). Jepang merupakan eksportir ban berkualitas tinggi ke Amerika Latin, dan menempati posisi ke dua setelah Tiongkok. Ban Tiongkok memiliki harga yang relatif lebih murah, sedangkan ban dari Amerika 
Serikat (seperti dari PT Goodyear) memiliki pangsa pasar yang luas.

$(-)$

\section{Kesempatan}

1. Menurut Kementrian Luar Negeri Republik Indonesia, FEALAC (Forum for East Asia and Latin America) didirikan untuk meningkatkan kerjasama komprehensif dan dialog biregional. FEALAC merupakan wadah kerjasama antar pemerintahan negara-negara di kawasan Asia Timur (16 negara) dan Amerika Latin (20 negara). FEALAC mewakili $40 \%$ populasi dunia, 32\% ekonomi dunia dan lebih dari $40 \%$ perdagangan dunia. Kerjasama ini merupakan kesempatan bagi Indonesia untuk memperluas pasar ekspornya dan meningkatkan perdagangan ban Indonesia. (+)

2. Penelitian Kementrian Perdagangan (2013) menunjukkan bahwa, jangka panjang nilai tukar berhubungan negatif dengan ekspor Indonesia. Pada jangka panjang nilai tukar yang melemah (depresiasi) akan meningkatkan ekspor Indonesia, termasuk ekspor ban Indonesia ke Amerika Latin. (+)

3. Hasil analisis EPD terdapat 6 Negara (Panama, Venezuela, Uruguay, Meksiko, Guatemala, dan Costa Rica) yang berada pada posisi rising star, yaitu pangsa pasar serta permintaan terhadap ban Indonesia cenderung meningkat. (+)

\section{Kebijakan Pemerintah}

1. Peraturan Presiden RI nomor 28 tahun 2008 tentang kebijakan industri nasional, memutuskan untuk mengembangkan investasi industri ban untuk menjadi salah satu basis industri ban dunia. (+)

2. PP 52 tahun 2011, pemerintah memasukkan industri ban sebagai kelompok industri yang memperoleh fasilitas tax allowance. (+)

3. Pencabutan Peraturan Menteri Perdagangan (Permendag) Nomor 40/M-DAG/PER/12/2011 tentang Verifikasi atau Penelusuran Teknis Impor dan menerbitkan Permendag Nomor 45/M-DAG/PER/6/2015 Tanggal 29 Juni 2015 Tentang Ketentuan Impor Ban. Peraturan ini bertujuan untuk memperketat impor ban dan mendukung industri ban nasional. $(+)$

4. Penghapusan Permendag No 45/MDAG/PER/6/2015 dan pemberlakuan kembali Permendag No 40/M-DAG/PER/12/2011 sebagai bagian dari paket deregulasi kebijakan September I. Kebijakan tersebut akan melonggarkan impor ban, sehingga dapat melemahkan industri ban nasional. (-).

\section{KESIMPULAN DAN SARAN}

\section{Kesimpulan}

Simpulan yang dapat diambil dari penelitian ini adalah sebagai berikut.

1. Ban Indonesia memiliki daya saing yang kuat di kawasan Amerika Latin, kecuali di Argentina. Pasar ban Indonesia berada pada posisi falling star di Brazil, Kolombia, Paraguay, dan Argentina. Posisi rising star terjadi di Panama, Venezuela, Meksiko, Guatemala, Uruguay, dan Costa Rica.

2. Faktor GDP riil perkapita, Nilai tukar riil, dan populasi di negara tujuan ekspor berpengaruh positif dan siginifikan terhadap ekspor ban Indonesia. Sedangkan GDP 
perkapita Indonesia dan jarak ekonomi berpengaruh negatif.

3. Ban Indonesia memiliki keunggulan kompetitif, dimana kondisi terkuat adalah kondisi faktor, terutama bahan baku karena Indonesia merupakan salah satu negara penghasil karet alam terbesar di dunia.

\section{Saran}

Saran yang dapat diberikan adalah sebagai berikut.

1. Pemerintah terus meningkatkan ekspor ban ke 6 negara yang menempati posisi rising star dan memiliki daya saing yang kuat yaitu di Meksiko, Panama, Guatemala, Venezuela, Uruguay, dan Costa Rica. Di negara yang menempati posisi falling star namun memiliki daya saing yang kuat yaitu Brazil, Kolombia, dan Paraguay, sebaiknya Pemerintah melakukan peningkatan mutu, promosi dan kerjasama dengan negara tersebut. Negara Argentina memiliki daya saing yang rendah dan menempati posisi falling star, sebaiknya ada diversifikasi produk karena ban tidak memiliki daya saing yang kuat dan pangsa pasar yang tidak dinamis di Argentina.

2. Berdasarkan hasil gravity model, GDP riil perkapita negara tujuan berpengaruh sangat besar terhadap nilai ekspor produk ban Indonesia. Sebaiknya Indonesia terus mennggencarkan ekspor ke negara dengan GDP riil perkapita yang tinggi.

\section{DAFTAR PUSTAKA}

Acharya, S. 2013. A Panel Data Analysis of Foreign Trade Determinants of Nepal: Gravity Model Approach. NRB Economic Review, vol. 25, 1-20.
[APBI] Asosiasi Perusahaan Ban Indonesia. 2008-2013. Laporan Tahunan. APBI, Jakarta.

Balassa B. 1965. Trade Liberisation and Revealed Comparative Advantage. The Manchester School. UK

Basri F, H Munanadar. 2010. DasarDasar Ekonomi Internasional Pengenalan dan Aplikasi Metode Kuantitatif. Kencana Prenada Media Group. Jakarta.

[BPS] Badan Pusat Statistik. 2016. Nilai ekspor Indonesia berdasarkan negara tujuan tahun 2008-2014. http//www.bps.go.id. [2016 Jan 24]

[CEPII] Centre d'Etudes Prospectives et d'Informations Internationales. Geodesic Distances.. Tersedia pada:

http://www.cepii.fr/distance/dist_c epii.zip [2016 Feb 3]

Deardoff A. 1997. Determinants of Bilateral Trade : Does Gravity Work in a Classical World?. University of Chicago Press. Chicago.

[Ditjenbun] Direktorat Jenderal Perkebunan. 2016. Luas areal dan produksi perkebunan seluruh Indonesia menurut pengusahaan. Tersedia pada: http://www.ditjenbun.pertanian.go .id [2016 Feb 1]

Esterhuizen. 2006. Measuring and Analysing Competitiveness in The Agribusiness Sector: Methodological and Analytical Framework. University of Pretoria. Petroria.

Evasari, U. 2014. Dampak Fasilitasi Perdagangan Terhadap Ekspor Elektronika Indonesia ke NegaraNegara Anggota APEC. Skripsi. IPB. Bogor.

[Gapkindo] Gabungan Perusahaan Karet Indonesia. 2016. Industri Kulit, Karet dan plastik Masih 
Prospektif untuk Dikembangkan. http://www.gapkindo.org [2016 Feb 20]

Haditaqy A. 2015. Analisis Daya Saing dan faktor-Faktor yang Memengaruhi Permintaan Ekspor Teh Hitam Indonesia ke Negara Tujuan Ekspor [skripsi]. IPB. Bogor.

Hatab AA, Romstad E, Huo X. 2010. Determinants of Egyptian Agriculture Exports: A Gravity Model Approach. Modern Economy. 1:134143.doi:10.4236/me.2010.13015.

Head K, Mayer T. 2013. Gravity equations : Workhorse, toolkit and cookbook. Sciences Po Economics Discussion Papers. No.02.

[ITC] International Trade Center. 2016. Existing and potential trade between Indonesia and Latin America and the Caribbean. Tersedia pada http://www.trademap.org/Bilateral _TS.aspx. [2016 Feb 4]

Karagoz K, Saray MO. 2010. Trade potential og Turkey with AsiaPacific Countries: Evidence from Panel Gravity Model. International Economic Studies. 36(1): 19-26.

Karlinda F. 2012. Analisis Daya Saing dan Faktor-Faktor yang Memengaruhi Permintaan Espor Mutiara Indonesia. Skripsi. IPB. Bogor.

[Kemenperin]

Kementrian Perindustrian. 2016. Industri Ban Diandalkan. Tersedia pada: http://www.kemenperin.go.id [2016 Feb 13]

Kementrian Perindustrian. 2016. Industri Karet Sintetis Butuh Investasi US\$ 1M Tersedia pada: http://www.kemenperin.go.id. [2016 Feb 2].
Kementrian Perindustrian. 2016. Saleh Husin Tantang Industri Serap Karet 40 Persen Tersedia pada

http://www.kemenperin.go.id [2016 Jan 30]

[KEMLU] Kementrian Luar Negeri Republik Indonesia. 2016. FEALAC [Internet]. [diunduh pada Feb 2]. Tersedia pada: http://www.kemlu.go.id

Krugman PR. 2009. International Economics: theory and policy. Pearson. Boston.

Li K, Song L, Zhao X. 2008. Component Trade and China's Global Economic Integration. UNU-WIDER Reasearch Paper 101: 1-23.

Lipsey R, G Courant, CTS 1993. Pengantar Makroekonomi Eds 10. Jilid 2. Terjemahan. Binarupa Aksara. Jakarta

Mankiw NG. 2007. Makroekonomi Edisi Keenam. Liza F, Imam N, penerjemah; Hardani W, Barnadi D, Saat S, editor. Erlangga. Jakarta. Terjemahan dari: Macroeconomics. Ed ke-6.

Nayantakaningtyas JS, Daryanto HK. 2012. Daya Saing dan Strategi Pemngembangan Minyak Sawit Indonesia. JMA. 9(3).

Porter ME. 1990. The Competitive Advantage of Nation. The Free Press, New York.

Pradipta A, Firdaus M. 2014. Posisi Daya Saing dan Faktor-Faktor yang Memengaruhi Ekspor BuahBuahan Indonesia. JMA. 11(2).

Salvator D. 1997. Ekonomi Internasional. Erlangga. Jakarta.

Tinbergen, Jan. 1962. Shaping The World Economy Policy. Twentieth Century Fund. New York.

[UNCOMTRADE] United Nations Commodity Trade. 2013-2016. 
UNCOMTRADE Statistics

Database

2013.

www.un.comtrade.org. [Diunduh pada 2016 Jan 23].

[UNCTAD] United Nations Conference on Trade and Development. 2016. Data Center Economic Trends. http://www.unctad.org. [diunduh pada 2016 Feb 2]

Yuniarti D. 2007. Analisis Determinan Perdagangan Bilateral Indonesia Pendekatan Gravity Model. JEP. 12(2): 99-109. 


\section{LAMPIRAN}

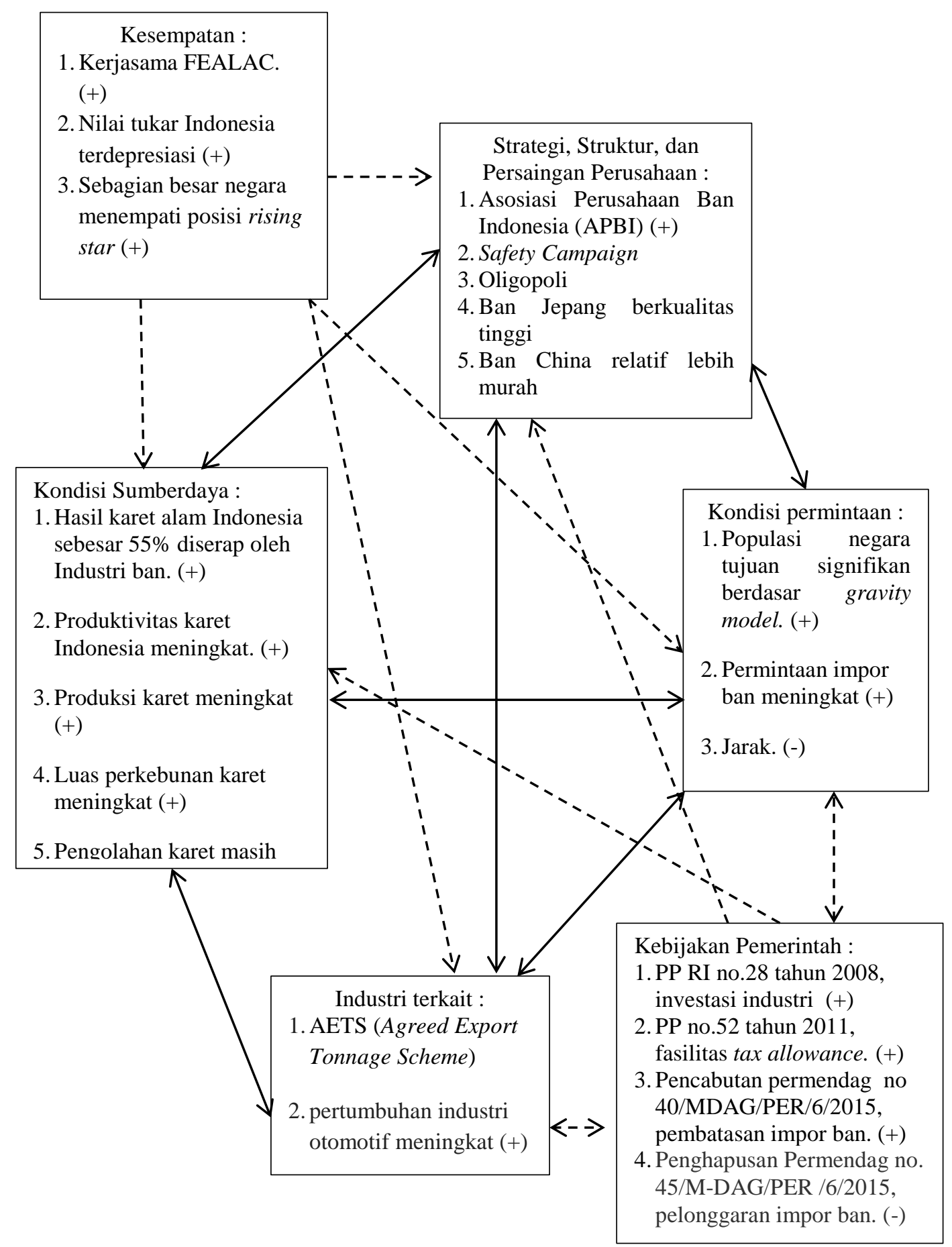

Gambar 7 Diagram analisis Porter's Diamond komoditi ban 